\title{
SELF-RAPISTS, ADULTERERS AND UNRELENTING INQUISITORS - HOW BOGUSLAW BUTRYMOWICZ AND EDMUND CIEGLEWICZ INTRODUCED ARISTOPHANIC COMEDY INTO POLISH READING CULTURE
}

ABSTRACT: In this article, I would like to reflect on the question of the introduction of Old Attic comedy to Polish reading culture. My main source for trying to reconstruct how Aristophanes' comedies have been brought into Polish reading culture is the first "complete" translations produced at the beginning of the $20^{\text {th }}$ century by Bogusław Butrymowicz and Edmund Cięglewicz. We are still in the period parallel to the Victorian era in England, so we can apparently predict, before even getting down to reading, what both the authors' translation strategies may look like, especially in the face of Aristophanes' prolific sexual innuendos. It turns out, however, that each of the authors being reviewed by me somehow tried to pick up the gauntlet which had been thrown down by the ancient playwright. Their courage to translate the original meanings without beating about the bush surprises us many a time, especially when we compare the Polish translations by them with those made into English by Benjamin Bickley Rogers, in the same period. Both Butrymowicz and Cięglewicz worked directly on the original Greek texts. Their prose translations released by the most popular publishers enabled outsiders to the small circle of experts to read pieces of ancient literature. As for pupils, students, theatre directors and theatregoers, their first (and usually only) contact with Aristophanes was by reading those translations. 
KEY WORDS: Aristophanes, reception, comedy, Poland, translations, Butrymowicz, Cięglewicz

In this article, I would like to reflect on the question of the introduction of Old Attic comedy to Polish reading culture. In the Middle Ages as well as in the Renaissance, only classical scholars and their students focused on Aristophanes' comedy texts (in properly expurgated form, of course). Initially, the main obstacle to popularizing his works was their obscenity and numerous references to Greek history and culture, most of which the Polish reader found too difficult to interpret. When the passage of time brought three consecutive partitions of Poland, the occupational authorities constituted another obstacle; it was censorship. So we can actually date Poland's full accessibility to Aristophanes' comedy writing at about the beginning of the $20^{\text {th }}$ century. ${ }^{1}$

The first documented edition of his comic plays in the Polish library collections, titled Aristophanis Facetissmimi Comici: Plutus (now stored as The Bavorovski Foundation collection in The Lviv National Scientific Library), dates back to $1531 .^{2}$ It was printed in Nuremberg by Johann Petreius, a German printer, who became fairly famous for having printed Nicolaus Copernicus' De Revolutionibus Orbium Coelestium, twelve years later. In the late $16^{\text {th }}$ and early $17^{\text {th }}$ century, first attempts to translate Aristophanes into Polish were undertaken by: Szymon Szymonowic and Piotr Ciekliński. ${ }^{3}$ They were both employees of The Zamojski Academy, the first private institution of higher education founded on Polish soil (1594), which was soon to become one of the major centres for Polish science and culture. Unfortunately, no fragments of their work on Greek comedy plays have been preserved. Relegated to the periphery of culture

See Michalik 2004: 36-37.

See Dolnośląska Biblioteka Cyfrowa, [online:] http:/www.dbc.wroc.pl/dlibra/ docmetadata?id=11009\&from=FBC [17 XI 2012]; Zbiory Lwowskie X. Biblioteka i Muzeum Baworowskich, Galeria Miaczyńskich-Dzieduszyckich oraz inne zbiory lwowskie, [online:] http://www.nimoz.pl/pl/wydawnictwa/czasopisma/cenne-bezcenneutracone-archiwum/2001/nr-22001/zbiory-lwowskie-x-biblioteka-i-muzeumbaworowskich-galeria-miaczynskich-dzieduszyckich-oraz-inne-zbiory-lwowskie/ print [30 VI 2013].

Starnawski 1992: 42. 
by Plautus and Terence, two far more popular comedy playwrights from the Roman Republic, Aristophanes had to wait until the $18^{\text {th }}$ century for some other humanists to try to introduce his works to the circulation of reading matter. These attempts have survived to the present day in fragmentary form only. It was surely not the best time yet to popularize such a radical author. 1772 saw partitioned Poland. Under the terms of the partition treaty, Poland's territory was divided among the Kingdom of Prussia, the Habsburg Monarchy and the Russian Empire. Warsaw, since 1815 being under Russian occupation, had its entire administration subordinated to tsarist authorities. The tsarist government imposed strict censorship and a ban on releasing any Polish-language publications. It seems that the utterly obscene Aristophanes with his love of politics was an unwelcome author in the territory of the terrorized-by-censorship Russian Partition (for a petty offence against the tsarist government, such as printing illegal texts, you risked being sentenced to many years of expulsion to Siberia for hard penal labour). Yet, around that time, despite such grave adversities, there was a student at the University of Vilnus who dared to make an attempt at translating Aristophanes' comedy plays into Polish - his name was Feliks Kołakowski. He belonged to a clandestine student organization, whose membership included activists in support of the restoration of Poland's sovereignty. The organization was detected by the tsarist police, and after a show trial, the members of the conspiracy were deported to Siberia (1823). Feliks Kołakowski is believed to have translated three Aristophanic comedy plays into Polish, but all three mysteriously disappeared without a trace. ${ }^{4}$

The situation in the Galician Partition (under the Habsburg Monarchy) was markedly different. The inhabitants of the southern areas of former Poland had much greater freedom than the Russian tsar's new subjects. Not only did Poles in the Galician Partition enjoy the right to use the Polish language (in both writing and speech), but they were also allowed to form their own political parties. Thus, the conservative Stańczyk party was established in 1869, and its social and literary interests would later on become closely connected with Aristophanes' comedy writing (a similar phenomenon can be observed in the experience of the

$4 \quad$ Starnawski 1992: 50. 
Tory party in Great Britain). ${ }^{5}$ Both these parties quickly adopted that ancient playwright as "their own". With regard to the successive theatrical stage productions of Aristophanes' comedy as well as to the title of "Polish political author" conferred upon him, we should particularly take note of the Polish translation of The Knights made by Józef Szujski. ${ }^{6}$ The "political status" of the translator of this most politicized comedy play by Aristophanes is incredibly essential in this instance. Józef Szujski (1835-1883), a Polish historian, a deputy in The House of Lords of the Viennese Parliament, basically gained his national fame in Poland as one of the most active members of the conservative Stańczyk party.

The only sources I will use in my attempt to reconstruct how Aristophanes' comedies were introduced into Polish reading culture are early $20^{\text {th }}$-century translations of entire works published in book form. However, it is paramount to keep in mind that a frequent way of popularizing Aristophanes' output was by publishing short fragments of his comedies in newspapers and periodicals, such as Kurier Lwowski [Lvov Courier], Stowo Polskie [Polish Word] and Museion. The editors of those periodicals included Henryk Lewestam, ${ }^{7}$ Franciszek Konarski ${ }^{8}$ and Józef Jedlicz, ${ }^{9}$ who were also the translators of the published passages. It is often hard to consider such fragments translations because most of them are prose summaries. (The chief reason why all those authors preferred to publish Aristophanes' comedies in an abridged manner was, for the most part, their vulgar character. These press publications of Aristophanic comedy fragments may be deemed just a supplement, and while they contributed to the popularization of Aristophanes' comedy, they did not have any significant influence on its general perception. As such they will be excluded from the present study. This hypothesis can be applied to Polish readers in the Galician Partition, as they enjoyed full access to the book market there. Nevertheless, we must employ a slightly different approach as regards the other two occupied territories. Most probably, the publication of Zygmunt Węclewski's truncated "translation" of The Birds in the pages of Biblioteka Warszawska [The Warsaw Library] was

Nowaczyński 1909: 110.

See Szujski 1887.

Starnawski 1992: 50.

See Konarski 1895; Konarski 1900.

Jedlicz 1954. 
the only occasion to familiarize a wider readership with Aristophanes, within the tightly sealed borders of the Russian Empire, and as such cut off from the outside world. ${ }^{10}$ Certainly, another difficulty in publishing The Birds lay in its plot: the lead characters search for an ideal place to live and they finally create it themselves by building a city between the earth and the sky. The undertone of the message could not escape the careful attention of the tsarist censors in the territory of an occupied country.

Furthermore, quite a few fragmentary translations of Aristophanes' comedies were published by those authors who also translated entire works by him. This is especially true of those comedies which they were unable to get published in full. Bogusław Butrymowicz - the same writer whose activity at the beginning of the $20^{\text {th }}$ century, along with that of Edmund Cięglewicz, caused Krakow's and Lvov's bookshop shelves to be massively packed with Polish translations of Aristophanes - published his "synoptic translation" of The Wasps in $1911^{11}$ and fragments of Peace in 1918. ${ }^{12}$ Particularly interesting is the introduction to the former, published in "Museion", because it allows us to observe how those early- $20^{\text {th }}$-century translators made their ancient author known to readers:

Arystofanes, nieubłagany inkwizytor maniactw i szaleństw swojej ojczyzny, jednym szturmem genialnego rozumu rozbija tę górnobrzmiącymi frazesami drapowaną przewrotność, ten obłęd samobójczy, tę fałszywą nieprawą zasadę $\mathrm{w}$ pył obrzydliwej rzeczywistości, każąc sędziwemu heliaście ateńskiemu sądzić z całą powagą... dwa psy! (...) Jaka przepaść, zgrozą przejmująca, pomiędzy świętą ideą sprawiedliwości niegdyś a dzisiaj, i czy można tę różnicę wyobrazić straszniej i zuchwalej? Każda komedya Arystofanesa to rodzaj szarpiącej nerwy operacyi na niedającym się już wyleczyć organizmie państwowym i społecznym Aten. (...) Doprowadziła do tego nieokiełznana niczem demokratyczna zasada, najwyższy ideał Ateńczyków, zwleczony z wyżyn jasnych na „bruk” ulicz-

\footnotetext{
$10 \quad$ Węclewski 1875: 398-434.

11 Butrymowicz 1911: 26.

12 Butrymowicz 1918: 27.
} 
ny, poniewierany i dławiony brutalną pieszczotą tłumu, wreszcie stopą szaleństwa politycznego strącony w bezdenną otchłań niewoli. ${ }^{13}$

Aristophanes, an unrelenting inquisitor against his country's manias and lunacies, is able - in just one storming attack by his brilliant mind - to crush into dust of disgusting reality all of that perversity draped in loftysounding slogans, all of that suicidal insanity, that false and unrighteous principle, by making an aged heliast judge, in all seriousness ... two dogs! (...) What an awe-inspiring abyss between the sacred idea of justice in the past and in the present, and could this difference be expressed better and more audaciously? Each comedy by Aristophanes is a kind of nerve-wracking operation on the already incurable organism of the state and society of Athens. (...) What led to it all came from the never-tamed democratic principle of freedom - the highest ideal for Athenians, now dragged down from its brightest heights to become shattered against the "dirty" street, kicked around and suppressed by the brutal caress of the mob and eventually cast into a fathomless chasm of thraldom by the boot of political madness. ${ }^{14}$

Powerful and frequently surprising historical comparisons as well as massive emotional charge and unshakable faith in the genius of Aristophanes are the most common elements that can be noticed in both Bogusław Butrymowicz's and Edmund Cięglewicz's translations. ${ }^{15}$ We are still in a period contemporaneous with the Victorian era in England, so we can apparently predict, before even getting down to reading, what the translation strategies employed by the two authors may look like in the face of Aristophanes' prolific sexual innuendos. It seemed almost impossible for Krakow's conservative bourgeoisie to tolerate, either on paper or on stage, any type of Aristophanic saucy wisecracking, especially if it had been perfectly translated from his Greek texts. Discretion with respect to any discussion of human corporeality and intimacy (even in a jocular manner), which is stereotypically attributed to those times, conditions our predetermined assumptions about how

\footnotetext{
13 „Museion” 1911: 28-29.

14 Butrymowicz 1911: 28-29.

15 See Nycz 1997: 43-44.
} 
Aristophanes' comedies had to be translated in that period. ${ }^{16}$ It turns out, however, that each of the authors under consideration somehow tried to pick up the gauntlet which had been thrown down by the ancient playwright. Bogusław Butrymowicz, despite being rather conventional in his translations, had no problem about making use of expressions such as "samogwałtnik" [self-rapist], 17 "samcołożec" [homosexual; or more in the spirit of the original - "ladulterer"]) ${ }^{18}$ and "uprawianie nierządu" [practice of harlotry]. ${ }^{19}$ Their courage to translate the original meanings without beating about the bush surprises us many a time, especially when we compare their Polish translations with those into English by Benjamin Bickley Rogers, in the same period. ${ }^{20}$ And what might seem even more surprising is the fact that the versions by Butrymowicz and Cięglewicz prove to be much more courageous than most contemporary translations by Janina Ławińska-Tyszkowska. ${ }^{21}$

While presenting the first full translations of Aristophanic comedy texts into Polish, I also wish to point out how Bogusław Butrymowicz and Edmund Cięglewicz endeavoured to convey the motifs characteristic of Greek culture and the Greek comedy genre. Both Butrymowicz and Cięglewicz worked directly on the original Greek texts. Their prose translations released by the most popular publishers enabled outsiders to the small circle of experts to read pieces of ancient literature. ${ }^{22}$ As for pupils, students, theatre directors and theatregoers, their first (and usually only) contact with Aristophanes was by reading those translations. A translator preparing a Polish version for such a well-defined target audience assumed the role of an "intermediary" between two worlds. The ancient text had to be presented not only as an attractive proposition to the theatre, but firstly it had to become a magnet for the reader to make him or her feel enchanted by the ancient author's imagination, during those long hours of silent reading. First "Slavonic" features, such as a typically emotional approach to the main topics, are observable al-

\footnotetext{
$16 \quad$ See Foucault 1995: 14.

17 Butrymowicz 1922: 24.

18 Butrymowicz 1922: 879.

19 Butrymowicz 1922: 167.

20 Rogers 1911.

$21 \quad$ Ławińska-Tyszkowska 2001 ( $1^{\text {st }}$ edition: Warsaw 1970).

22 Hutnikiewicz 2000: 391.
} 
ready in the introductions to the translations under discussion. Those introductions, composed by the translators themselves, were meant to highlight the historical and cultural context, in which the Athenian playwright, relatively unknown in Poland, had written his works. Most readers, encouraged by the introduction, made up their minds to continue reading the book. As a result, we can conclude that the foreword was the best written part of the entire translation. In general, all those introductions - added by the translators, who lived and worked during Polish neo-romanticism - allow us to investigate more than just their stylistics and methods for bringing Aristophanes into Poland's reading experience at the beginning of the $20^{\text {th }}$ century. They also provide us with an outline for the alleged level of knowledge about Aristophanes that an average reader (that is, one not dealing with ancient literature day in, day out) may have possessed. ${ }^{23}$ Of course, the modern reader feels irritated by frequently noticeable dissonance between the translators' high register and the real semantic value of their description. From the perspective of today's language standards, those translators' stylistics is so overloaded with exaggerated emotionality and poetic imagery that it dangerously borders on bad taste, which we naturally blame on the epoch those translations were made in:

Komedia grecka była wytryskiem temperamentu greckiego ludu. (...) najbardziej charakterystyczną cechą komedii (...) jest wolność, swoboda, samowola, zaiste posunięta do granic jak najdalszych. Jest to także pewnego rodzaju ochlokratyzm ${ }^{24}$, ochlokratyzm sceniczny, przeciwstawiony ochlokracji politycznej, komediowładztwo w całym tego słowa znaczeniu, nie mające odpowiednika w dziejach wszechliteratury, odrzucające wszelkie pęta, obawy i względy, odpowiedzialne jedynie przed trybunałem piękności i prawdy. (...) Poeci komiczni usposobieni arystokratycznie albo bezpartyjnie, wprowadzają do swoich utworów rodzaj cenzury, w formie bezpośredniej przemowy do publiki, parabazy, i ten wszczepiony w łono komedii człon, jest sędzią, satyrą i biczem, którym geniusz narodu i człowieczeństwa ześrodkowany, i zindywidualizowany $\mathrm{w}$ duchu poety, chłoszcze bezlitosną satyrą, sie-

23 See Terlikowski 1912: 157-158.

24 ó $\chi \lambda$ ократí $(\mathrm{Gr}$.$) - rule of the crowd.$ 
cze do krwi ułomny wieczyście organizm ludzki i jego nieustannie powtarzające się w różnych formach, a przecież tak jednoistotne wytwory: państwo, społeczność, życie publiczne i prywatne, pychę powszechną i ambicję jednostkową, i śmieszność nieśmiertelną, niczem niespożytą śmieszność. ${ }^{25}$

Greek comedy was a spurt of the Greek commonalty's temperament. (...) $[\mathrm{T}]$ he most characteristic quality of this type of comedy (...) is its freedom, latitude, wilfulness, truly carried to the ultimate extremes. It is also some sort of ochlocratic regime, an ochlocratic stage regime against a background of political ochlocracy, comediocracy par excellence, without precedent in the entire history of all literature, which rejects any chains, fears and considerations and is answerable only to the tribunal of truth and beauty (...) Comedy poets with an aristocratic attitude or a nonparty attitude impose a kind of censorship on their own works, in the form of a direct speech to the audience, a parabasis; and that one segment implanted into the heart of comedy is a judge and a scourge, with which the genius of humanity and of the nation - centred and individualized as the spirit of a poet - flogs the eternally crippled human organism until blood flows, using his merciless satire, and also flogs this organism's creations, constantly changing form and yet homomorphic, such as state, society, public and private life, ubiquitous hubris and individual ambition, as well as immortal ridiculousness - that never-tamed ridiculousness. ${ }^{26}$

Bogusław Butrymowicz (1872-1965), the author of the aforecited introduction and the translation of Aristophanes' comedy The Knights, studied classical philology at the universities of Krakow and Vienna. He translated works of Aristophanes, Euripides and Friedrich Schiller. He also had two chapbooks of his poetry published: The Poems (1897) and Following the Sun (1898). ${ }^{27}$ Unrestrained, from today's reader's viewpoint, the emotionality of the forewords to those translations of Aristophanic comedies is characteristic of all the publications under review, those by Butrymowicz as well as those by Cięglewicz. Luckily,

25 Butrymowicz 1922: 3-7.

26 Butrymowicz 1922: 3-7.

27 Podraza-Kwiatkowska 1977: 81 and 232. 
Butrymowicz did not focus on reading the lines of the comedies only at an emotional level or in reference to his own subjective beliefs. Apart from those, he conveyed to his reader the most necessary information on Aristophanes' life and on the development of the comedy genre (in regard to which, he mentioned less-known authors, such as Epicharmus of Kos, Cratinus and Crates). ${ }^{28}$ Moreover, he depicted the historical context, in which The Knights had been staged.

Edmund Cięglewicz (1862-1928) was a Krakow-based journalist. His own translations of Aristophanic comedies were being published "in parallel with" Bogusław Butrymowicz's versions. Displays of affectation and what appears to the modern eye as excessive exhibitionism of emotional involvement with the topic reach their apogee in Cięglewicz's preface to his translation of The Frogs from 1906. Cięglewicz describes the final phase of the Peloponnesian War in the following way:

Czuć początek końca... (...)

Młode pokolenie - pod wpływem wszechmożnej ochlokracji i ustawicznej wojny - zdziczałe: rośnie rozpusta, hazard, obojętność na zysk lub stratę, cyniczna pogarda śmierci i zużycie przedwczesne (...)

w Atenach gazduje Teramenes, typ zaprzedańca dyplomaty (...) tajny zwolennik Targowicy, zezującej ku Sparcie. (...)

Alkibiades uchodzi powtórnie i... na zawsze.

Zdaje się, że bogowie sami odwrócili się od Aten.

Nie ma wodzów.

Zginęli w boju, poszli pod topór katowski lub na wygnanie.

Nie ma myślicieli-statystów.

Diagoras, Protagoras, Gorgiasz na obczyźnie.

Nie ma poetów...

Ajschylos, Sofokles, Eurypides nie żyją, młodziutki a genialny Eupolis zginął gdzieś w utarczce.

Lud płacząc po nim, wydać miał uchwałę, aby odtąd żaden poeta nie szedł na wojnę. (...)

Nadchodziły świątki Lenajskie, czas wystawiania sztuk nowych. I nie raz zabrzmiało pytanie, czy to na Pnyksie, czy to na agorze, czy w gim- 
nazjum, czy też na Akropolu, pytanie ust wielu, pytanie wiszące w powietrzu: „I któż nam teraz napisze dramat, kto nam da nową tragedię?”„Tak, to prawda: Ach! gdybyż ci nasi mistrze, gdybyż który z nich wstał z mogiły!" I tu występuje Arystofanes ze swoją komedią Żab. ${ }^{29}$

the beginning of the end can be sensed... (...)

The young generation - under the influence of overpowering ochlocracy and continual war - have become wild; debauchery, gambling, indifference to gains and losses, cynical contempt for death, and premature exhaustion are on the rise (...)

Theramenes, a renegade-diplomat type of man, is governing the home and farm of Athens (...) he is a clandestine supporter of the Targowica Confederation, looking sideways at Sparta. (...)

Alcibiades is fleeing again and... for ever.

It seems as if the gods themselves have turned their backs on Athens.

There are no leaders.

They have all died in battle, been axed or gone into exile.

There are no extras to play thinkers.

Diagoras, Protagoras, Gorgias are in exile.

There are no poets...

Aeschylus, Sophocles, Euripides are dead; the young and brilliant Eupolis has been killed in a skirmish somewhere.

The people, whilst mourning for him, have issued a resolution that no poet should ever go to war, from this day forward. (...)

The Lenaia festival is approaching, the right time to stage new plays. And many a time, the same question has been uttered - on the Pnyx and in the Agora, in the gymnasium and on the Acropolis - a question repeated by word of mouth, a question left hanging in the air: "And who shall now write a drama for us, who shall provide us with a new tragedy?" "Yea, that is true: Oh, if only those word masters of ours, if any of them rose from the grave!" And this is where Aristophanes enters with his comedy entitled The Frogs. ${ }^{30}$ 
If we leave aside the emotionality and reduce the passage above to historical facts only, Cięglewicz plainly portrayed the situation of Athens in $405 \mathrm{BC}$ in a manner we know from widely available specialist literature. However, the terms and phrases he employed are worth a prolonged moment of attention due to their interesting linguistic and historical references. The modern reader may be somewhat surprised at the phrase "Theramenes is governing the home and farm", in Polish "Teramenes gazduje", because the use of the verb "gazdować" is typical of the Podhale dialect, which is rarely or barely spoken. ${ }^{31}$ The verb "gazdować" (to govern the home and farm) derives from "gazda", meaning "house and farm owner" in the region of Podhale. ${ }^{32}$ This linguisticgeographical stylistic figure still does not attract as much attention as another device (in the same passage) applied by Cięglewicz, one that is even more surprising because it combines elements belonging to two completely different historical contexts: how on earth is Theramenes, an Athenian politician of the fifth century BC, supposed to be a supporter of the Targowica Confederation established at the end of the eighteenth century AD? Why is an event of Poland's history suddenly referred to in an account of the Peloponnesian War? The modern reader might treat that fragment as a translation oddity, yet Cięglewicz had carefully ruminated on what to replace the little-known Thirty Tyrants with. The name "Targowica" in Poland has ever since been regarded as a historical symbol of national treason; ${ }^{33}$ however, the use of this name in a translation of Aristophanes' comedy play has a double meaning in this case. On the one hand, Cięglewicz vividly conveys the branding of Theramenes as a traitor; on the other hand, he succeeds in maintaining one of the most essential features of Old Attic comedy - its creators and authors made

\footnotetext{
$31 \quad$ Balcerzan 1998: 108.
}

32 A geographical and cultural region in Southern Poland, at the northern base of the Tatras.

33 The Targowica Confederation was officially founded during the night of 18-19 May 1792, in a small Ukrainian town of Targowica. A number of Polish magnates, interested in eliminating the reforms adopted by the Four-Year Sejm and the Constitution (signed on the $3^{\text {rd }}$ of May 1791), made a deal with Tsarina Catherine II. In accordance with that deal, the members of the Targowica Confederation turned to Catherine II for military assistance in order to restore Poland's former political system. On 23 May 1792 the Russian Army entered the territory of Poland. 
extremely frequent references to various historical events, best known to the local community. The only remaining problem lies in the lack of an explanatory comment that could make it easier for a reader unfamiliar with the nuances of Greek comedy to understands the purpose of such stylistic treatment. It is a very common practice to explain the meaning of a new element by comparison to something well known. ${ }^{34}$ That is exactly the strategy Cięglewicz applied. He preferred avoiding the slow and laborious presentation of the political realities during the Peloponnesian War and - so as to introduce Theramenes to the Polish reader as a betrayer - made use of a historical event that the latter knew well and which was fairly easy to interpret. (Sparta was included here for the sake of maintaining historical decorum.) For a bibliophile, bored with modern, philologically sophisticated translations, this stylistic trick, so popular at that time, is both astounding and ravishing. It reveals what sort of great intellectual adventures the translator could experience in pursuit of equivalence.

Bogusław Butrymowicz's introduction to the same comedy, published two years later, differed substantially in the sphere of stylistics. First and foremost, it was free of decadent and nihilistic descriptions, which in the case of Ciegglewicz combined ancient Greek pragmatism with Polish neo-Romantic love for everything, which was beyond rational control. Butrymowicz cast light on the social situation that had existed in the world of flourishing Old Attic comedy as well as on its history, its leading writers and its mocking approach to everyday life and state politics. He methodically depicted the characteristic qualities of comedy plays in Aristophanes' days, such as brutal jocularity or parodic and caricatural representations of other personages in theatre. In contrast to Cięglewicz, he made every effort to make the presented facts and details explicable by the included Greek context. Butrymowicz's emotional attitude towards Aristophanes as well as his deep (and similar to Cięglewicz's) belief in the ancient playwright's genius are revealed as soon as the time is ripe for describing Aristophanes himself, after the historical and theoretical foreword:

$34 \quad$ See Rancière 2008: 71. 
Stanowisko Arystofanesa, jako przedstawiciela starszej komedii attyckiej, jest jedyne i pierwszorzędne. (...) Nigdy żadne państwo aż do dni naszych nie pozwalało sobie mówić tak gorzkiej prawdy, chłostać się tak zabójczo, bo aż do samego serca, jak Ateny za czasów Arystofanesa. Każda wada prywatna, społeczna, czy polityczna wije się formalnie pod straszliwymi cięciami jego satyry: państwu i społeczeństwu targa w strzępy świetne szaty pozorów nieubłagana chłosta, a człowiek tracąc pod biczem sztuczną skórę obłudy i kłamstwa, ukazuje zgangrenowaną krew, świecącą próchnem napełnioną duszę. (...) Z czysto artystycznego punktu widzenia będzie się Arystofanes zawsze zaliczał do największych poetów świata. Jego język jest niesłychanie misterny (przeczysty attycyzm), zdolny do oddania wszystkich odcieni, od najswobodniejszego dialogu do najwspanialszych dytyrambicznych pieni. Niesłychana elegancja słowa przepysznie odbija od brutalnej gwary ludowej i barbarzyńskiej greczyzny, którą się niejednokrotnie posługuje. Ta sama pogardliwa genialność, z jaką w utworach swoich całą naturę i świat ludzki rzuca sobie pod stopy, przejawia się także w jego słownictwie: za pomocą połączeń aluzji lub naśladowania różnych dźwięków w naturze i u istot żyjących, stwarza na wskroś oryginalne i niezmiernie wybitne wyrazy, co przy przekładzie jego komedii stanowi niepokonalną prawie zaporę. ${ }^{35}$

Aristophanes' position, as a representative of earlier Attic comedy, is unique and primary. (...) No country has ever since, until our days, taken the liberty of telling such bitter truth, of flogging itself murderously enough to penetrate its very heart as deeply as Athens did during Aristophanes' time. Every private, social or political fault begins wriggling formally under the frightful lashes of his satire: that unrelenting whipping keeps tearing the State's majestic robes of disguise to pieces; and man - whilst losing his fake skin of hypocrisy and deceit - reveals his gangrenous blood, his soul aglow with decay. (...) From a purely artistic point of view, Aristophanes will always be included among the world's greatest poets. His language is amazingly full of subtleties (immaculate Atticism), capable of expressing the whole gamut of shades from the most easy-going dialogue to the most magnificent dithyrambic hymns. The unheard-of elegance of his wording deliciously diverges 
from the brutal folk dialect and barbarian Greek he uses many a time. The same contemptuous ingeniousness with which he puts the entire human world and nature at his feet is also manifested in his vocabulary: by combining allusions or by mimicking various sounds of wildlife and living creatures, he forms thoroughly original and outstanding words; and those are the things that set up an almost unconquerable barrier to translating his comedies. ${ }^{36}$

Against a background of the historical facts and the genological factors neutrally described by Butrymowicz, there is a Man appearing there, all of a sudden. An ingenious artist whose satire kept the State pushing its limits on what was acceptable by the generally recognized social standards. The character of Aristophanes, seen as a prominent artistic individual, perfectly harmonized with the demand of the time in which the said translations were made. Aristophanes, who had been able to mercilessly unmask any disguise created by the human attitudes around him and to notice everything more accurately and more clearly, was portrayed as the Athenian audience's favourite child, allowed to say anything and everything on stage, even such things that would be most uncomfortable and most unfavourable to the authorities around that time. Not only was he portrayed as a man with great powers of observation - which let him pick out the most essential issues of the Athens of his time - but also as a man using the language of literature to convey all those nuances required for comic effect. Thus, Butrymowicz's preface is an introduction that very precisely deals with the historical facts; but it also shows us a vividly personal portrait of Aristophanes. It was extremely essential because this ancient playwright had not always been so well renowned in Poland before.

One of the biggest challenges to a translator of and a commentator on Aristophanes is the mass of details (such as names, hints at current events, intertextual references, etc.) deeply rooted in the history and culture of Athens of the $5^{\text {th }}$ century BC. Therefore, another key question (apart from any analyses of how the ancient author's output has been implemented into commonly accessible literary culture) lies in thorough research on some selected examples so as to understand how the

36 Butrymowicz 1908: 8-9. 
translators of the early $20^{\text {th }}$ century coped with what seemed most typical of Aristophanes' personality and of his literary genre. It often happens that a comedy cannot be interpreted fully without being hedged in by a powerful critical apparatus. An analysis of these two translators' work and careful comparison of the results obtained for each translation will make it possible - in addition to observing their translation strategies - to understand why Bogusław Butrymowicz's translations look so dull, when contrasted with the never-tamed imagination of Edmund Cięglewicz's Polish versions.

Butrymowicz very unwillingly presented the possibilities for staging the comedies translated by him. In his stage directions, he only provided that sort of descriptions and information, the authenticity of which he could ascertain on the basis of original sources (which are extraordinarily scanty as regards the visual arts in theatre in the $5^{\text {th }}$ century $\mathrm{BC}$ ). Wherever text passages lacking scholia and authoritative information allowed free rein to the translator's imagination, Butrymowicz remained conservative in his obvious belief that there should be no unconfirmed hypotheses imposed on the text. In exactly the same manner, he proceeded with explanations for facts and characters extracted from Greece's history. Butrymowicz most conscientiously led the reader of his translation through all the allusions, which became transparent and comprehensible only when their Greek context was fully explained. Of course, his term "the hamlet ${ }^{37}$ of Kydathineon" may seem a bit amusing in place of the word "demos" that he certainly had to be familiar with. On the other hand, any such paragraph in which there was a littleknown Greek name or a reference to some event (such as, for example, the Festival of Jugs; The Acharnians 961), or a symbol (for example, the Panathenaic robe; The Knights 566), was never left without a comment because Butrymowicz tried to explain the meaning of each foreign element the best way he could.

Unlike Cięglewicz, he rarely translated Greek elements by finding their equivalents in Polish literary terminology. In most cases, he did his best to remain within the scope of Greek culture. Nevertheless, we can still find some fragments, in which Butrymowicz deviated from

37 "Sioło" derived from the Russian word "село" - a hamlet or a village. Butrymowicz 1922: 10. 
that principle, and therefore, for instance, "eye of the king" (a term for the Persian agent) was rendered by him as "minister". A similar trick was used in the scene where Dionysus, defending himself from the Tavern Wench, like a madman, drew the cutlass from its sheath (The Frogs 563). While "minister" can slightly irritate us as a too modernized version of that Persian administrative function, the introduction of a cutlass to ancient weaponry is probably an unforgivable insult to every weapons expert. A cutlass, as a popular weapon of poorer social groups, made its first appearance in Western Europe as late as the end of the $12^{\text {th }}$ century. It seems likely that Butrymowicz used that name on purpose, in order to highlight the knavish personality of Dionysus in the comic representation. Yet, the word Gípos used by Aristophanes means nothing more than a common sword. Similar negligence can be detected in line 1017 of the same comedy play. Aeschylus talks about "vambraces" in Butrymowicz's translation. However, the

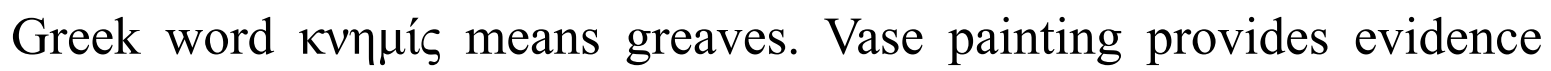
that greaves were actually worn by Greek soldiers, also by hoplites. Vambraces, as a component of protective armour for the forearms (not for the shins, unlike greaves) were introduced and used not earlier than in medieval times.

Cięglewicz remained helpless against the lack of sources in much the same way as Butrymowicz, preferring to replace details so well known in Greek culture with Polish elements. A centaur, one of the most popular creatures from Greek mythology, connected with so many sophisticated symbols and literary references, was translated by him as "haidamaka" (derived from Ukrainian: гайдамака), meaning a Ukrainian rebel in the $18^{\text {th }}$ century (The Frogs 35). Therefore, Cięglewicz deprived that entire passage of any possible references to the ancient world. With all certainty, the (uninvited) guest in Heracles' home was compared to a cen-

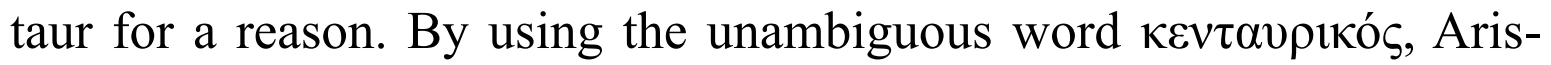
tophanes had to have in mind something more than just a dipsomaniacal creature full of insatiable sexual lust; he pointed out the following chain of associations: Heracles - the Centaur Nessus - the shirt of Nessus. It may well have been the case that Aristophanes' contemporary Athenian audience followed the same train of thought. There was no chance for such ways of interpretation in Cięglewicz's version. They were all replaced with a Cossack warrior, a figure mainly linked with Henryk 
Sienkiewicz's historical novels, so popular at that time. It was, of course, a use of Aristophanic intertextuality; yet, the question remains whether Greekness really had to be substituted with Polishness in almost every possible passage, and whether there was no other method?

The third day of Anthesteria (the so-called Day of Pots), an Athenian festival of ripening wine, held in honour of Dionysus, was traditionally dedicated to the dead and to Hermes Chthonius. Cięglewicz rendered that festival as “our Forefather's Eve (All Souls' Day), which was nonetheless celebrated in a very merry manner, with dances and Midsummer bonfires included." ${ }^{38}$ Ancient Greeks would certainly have been rather surprised if they had found out that a foreign translator deemed the festival of dead spirits coming to towns for young wine "merry". The very fact that the spirits of the dead were chased back to Hades should be a clue that their presence probably made nobody happy. The existing descriptions indeed suggest a grim festival, similar to the Slavonic celebration depicted in Adam Mickiewicz's Dziady [Forefathers' Eve]. Dziady 'forefathers' in Polish folk tradition was the name for dead spirits, who were summoned on All Souls' Day ( $2^{\text {nd }}$ November), during clandestine nocturnal meetings inside village churches or in graveyards (as the ritual was officially banned by the Catholic Church). The participants in such a meeting prepared a special supper for the dead, who were to arrive after being summoned by the Augurer (the eldest man at the meeting). The spirits to come were just purgatory souls, who could not pass through the pearly gates of Heaven because of their unfinished earthly affairs. The Augurer's crucial task (as the only person capable of communicating with the dead) was to ease their suffering and to enable the continuation of their journey.

Another example of Cięglewicz going somewhat too far was when

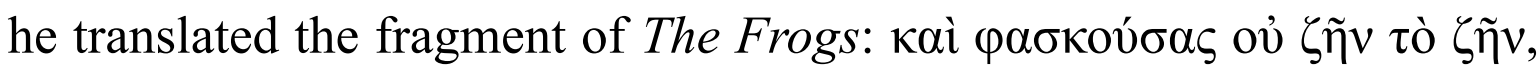
as: to be or not to be? (1083). This might have been perfect as a joke, but the original text was harmed again. The cited Greek fragment comes from Euripides' tragedy entitled Phrixus and was used by Aristophanes as an intertextual allusion. Judging by the style of Cięglewicz's translation manoeuvre, it is easy to recognize that he perfectly understood the function of that fragment in the structure of Aristophanes' comedy 
play. Cięglewicz decided to convey Aristophanes' allusion in a way that surely seemed to be more easily understood by the Polish reader. If the reader does not realize that Aristophanes in his texts made constant references to other authors' works, he or she cannot detect the fact that such is also the function (filtered through the modern culture code) of the quote from Shakespeare woven into the text of the comedy. The footnote explanation that it is a fragment from Hamlet's monologue will not suffice in this case.

Sometimes, Cięglewicz's similes are very touching in their directness. When Aeschylus remonstrates with Euripides on the ground that "he's been doing dirty exercise with the chorus, like with Kyrene the hetaera, in a sequence of twelve positions!" (The Frogs 1328-1329), Cięglewicz explains that during Aristophanes' time, Kyrene was a wellknown hetaera: "who, as we can see, was able to use twelve out of those Parisian quarante manieres. Progress is with us!"39

Butrymowicz never sought ways to employ such similes. He focused on conveying "Greekness" through its self-referential possibilities. The principle according to which Butrymowicz's translations were faithful and those by Cięglewicz were beautiful is still applicable. Cięglewicz obsessively searched for opportunities to introduce Aristophanes as an equal to modern writers. And, as we have already noticed, he often went beyond his level of competence as a translator while doing so. In his translation of The Clouds - a comedy play where one of the main motifs is the father's debt accumulated to help his son indulge equestrian passion - Cięglewicz converted the price of an ancient saddle horse into crowns, the then valid currency in the Galician Partition, in order to make the reader familiar with the scale of the problem. Strepsiades says that he borrowed 12 minas to purchase a bay horse (The Clouds 22-24). 1 mina, according to Cięglewicz's calculations, equalled about 100 kronen (Austro-Hungarian currency), so the reader knew that the stallion bought by Strepsiades cost about 1200 kronen. The statistics from that period show that "the average annual salary in Krakow, in 1905, was: 408 kronen for a night watcher, 960 kronen for an usher, and 18000 kronen for a city mayor." Everything is clear now: the son deserved a good beating, but the bay horse must have been like a dream.

39 Cięglewicz 1906: 100. 
Some other fragments allow us to investigate the theoretical and practical aspects of his work on the translation, particularly in situations when the translator needed consultation with an expert in a different domain. Cięglewicz, during his work on the Polish version of The Clouds, paid a visit to Professor W. Kulczyński so as to determine exactly, after 2311 years of evolution, what species of lizard Aristophanes had in mind in the following scene referring to Socrates:

As he was studying the moon's ways and changes

With his head lifted and his mouth wide open,

A lizard peed in it, straight down from the rooftop. (171-173)

Cięglewicz mentioned two Greek names, appearing in the original text:

- $\quad \sigma \kappa \alpha \lambda \alpha \beta \omega ́ \tau \eta \varsigma$ (from the disciple's earlier line) means Platydactylus mauretanicus, according to A Greek-English Lexicon by Henry Liddell and Robert Scott,

- $\quad \gamma \alpha \lambda \varepsilon \omega ́ \tau \eta \zeta$ (in the three-line fragment above) is defined in A GreekEnglish Lexicon as "gecko lizard" (without the Latin name of the species).

It only takes one look at photographs of the two lizards to understand that Cięglewicz's curiosity about the species of lizard Aristophanes actually described was not groundless. The two lizards significantly differ in colour and body shape. After consultation with Professor Kulczyński, the Polish translator explained that Aristophanes had definitely meant a European lizard "with very prominent finger pads and toe pads, deftly moving on walls and even on ceilings. Professor Kulczyński believes that it is a stellio, or a gecko, hated by housewives because, while freeroaming on the walls, it very often falls into their containers filled with milk and into their pots. Our folks say that a toad, when provoked to anger, makes the same indecent gesture as the Aristophanic lizard, which can blind you as a result." ${ }^{40}$ Obviously, it can be proved that descendants of the lizard peeing in Socrates' mouth still existed in Polish villages, at the beginning of the $20^{\text {th }}$ century.

40 Cięglewicz 1907: 47. 
The last comedy play, in which we can analyse the introduction of Polish elements to the Greek cultural circle, is Gromiwoja (Lysistrata) as translated by Cięglewicz. He sees disobedient women as revoltresses; he calls a probulos a director. And it is really heart-warming to come across "koshaleks" and "opaleks" 41 of unknown origin in the translated text of Aristophanes' comedy. He compares the boasts made by the chorus of old men to the braggadocio of one of the best-known characters in Polish literature, Mr. Zagloba - an imaginary symbol of Poland's noblemen. ${ }^{42}$ What does not seem even a bit less interesting is Cięglewicz's comparison of Cecrops and Pandrosos (the first king of Athens and his daughter) to Krak and Wanda, ${ }^{43}$ Kraków's legendary counterparts of the former.

The official editions of Butrymowicz's translations were released only shortly after Cięglewicz's versions. However, the differences between the translation strategies they had chosen were very considerable. Edmund Cięglewicz applied elaborate descriptions, often overloaded with redundant (from today's perspective) references to the translator's times, which muddy the image of ancient Greek comedy. On the other hand, he depicted his imaginary locations and details in a very picturesque fashion. He used the lack of existing scholia to his advantage by bridging that gap with his own visions of staging the play. He also took liberties with presenting the characters, the costumes and the chorus as well as the arrangement of their scenic movement, which were all thoroughly described in his stage directions. Another one of his talents was the ability to convey Aristophanes' variety of Greek dialects in the Polish version by stylizing his translation to make it sound like the folk dialect of the Tatra mountain region.

Butrymowicz, a translator younger than Cięglewicz, interpreted Aristophanes' comedies in a completely different way. Perhaps, the motivation behind his decision to avoid elaborate descriptions of the characters, the stage details and the chorus members was never to be

41 Cięglewicz 1909: 499-500. Koshalek Opalek, the name of an imaginary character from the Polish literary fairytale Dwarves and a Little Orphan Girl Mary by Maria Konopnicka, first published in 1896. Koshalek Opalek was a dwarf employed as the royal court chronicler of Blystek the Dwarf King.

42 Cięglewicz 1909: 114. Zagloba - one of the lead characters from The Trilogy, a cult historical novel by Henryk Sienkiewicz.

43 Cięglewicz 1909: 115. 
suspected of drawing any inspiration from his predecessor. Actually, in many passages we can clearly notice that Butrymowicz's translations are the very antithesis of Cięglewicz's adaptations. Wherever in the text Cięglewicz was absolutely carefree about his fanciful visions, Butrymowicz remained conservative. His scanty stage directions seem to be an act of humility towards the lack of existing sources. He resigned from picturesque descriptions of the performance. In this respect, his stage directions are only fragmentary. Yet, (in a way similar to Cięglewicz's) he tried to outline the actors' movements and the individual characters' emotions. The contemporary knowledge was a benchmark for his translations. Greece, to his mind, was an enclosed cosmos of facts and events, the interpretation of which was only possible through historical research. He always tried to stay very close to the original text, and he did not conceal the presence of a phallus in Dikaiopolis' procession (The Acharnians 242). And, what is more, he did not conceal the comically sexual allusion to the spears of men, which were supposed to be left home (The Acharnians 1060). If we compare both the translations, we could summarize them by paraphrasing Aristotle's statement: Cięglewicz shows the comedy texts as they should be introduced to the reader at the beginning of the $20^{\text {th }}$ century, and Butrymowicz shows them as they actually were. ${ }^{44}$

\section{BIBLIOGRAPHY}

Aristophanis Facetissmimi Comici: Plutus, 1531, [online:] http://www.dbc.wroc. $\mathrm{pl} /$ dlibra/docmetadata? $\mathrm{id}=11009 \&$ from $=\mathrm{FBC}$.

Balcerzan E., 1998, Literatura z literatury (strategie ttumaczy). Studia o przekładzie, Katowice.

Butrymowicz B., 1908, Arystofanes. Żaby, Kraków.

Butrymowicz B., 1911, 'Arystofanes. Osy', Museion 4, p. 26.

Butrymowicz B., 1918, 'Arystofanes. Pokój', Maski 22, p. 27.

Butrymowicz B., 1922, Arystofanes. Rycerze, Kraków.

Cięglewicz E., 1906, Arystofanes. Żaby, Kraków.

$44 \quad$ See Podbielski 1989: 1448a. 
Cięglewicz E., 1907, Arystofanes. Chmury, Kraków.

Cięglewicz E., 1909, Arystofanes. Gromiwoja, Kraków.

Cięglewicz E., 1911, Arystofanes. Chmury, Kraków.

Foucault M., 1995, Historia seksualności, Warszawa.

Hutnikiewicz A., 2000, Młoda Polska, Warszawa.

Jedlicz J., 1954, Arystofanes. Ptaki, Warszawa.

Konarski F., 1895, 'Arystofanes. Żaby (prolog w. 180-270)', Eos 2, pp. 68-73.

Konarski F., 1900, 'Arystofanes. Żaby (w. 316-415)', Eos 6, pp. 20-24.

Ławińska-Tyszkowska J., 2001, Arystofanes. Komedie, Warszawa.

Michalik J., 2004, Dramat obcy w Polsce 1765-1965: premiery, druki, egzemplarze: informator, Vol. 2, Kraków.

Nowaczyński A., 1909, Co czasy niosą?, Lwów.

Nycz R., 1997, Język modernizmu: prolegomena historycznoliterackie, Warszawa.

Podbielski H., 1989, Arystoteles. Poetyka, Wrocław.

Podraza-Kwiatkowska M., 1977, Młodopolski świat wyobraźni, Kraków.

Rancière J., 2008, Dzielenie postrzegalnego. Estetyka i polityka, Warszawa.

Rogers B. B., 1911, The Comedies of Aristophanes, London.

Starnawski J. (ed.), 1992, Antyk w Polsce, Vol. 1, Łódź.

Szujski J., 1887, Dzieła: Wydanie zbiorowe, Vol. 5, Kraków.

Terlikowski F., 1912, Życie publiczne, prywatne i umystowe starożytnych Greków i Rzymian, Kraków.

Węclewski Z., 1875, 'Arystofanes. Ptaki', Biblioteka Warszawska 3/95, pp. 398-434. 